
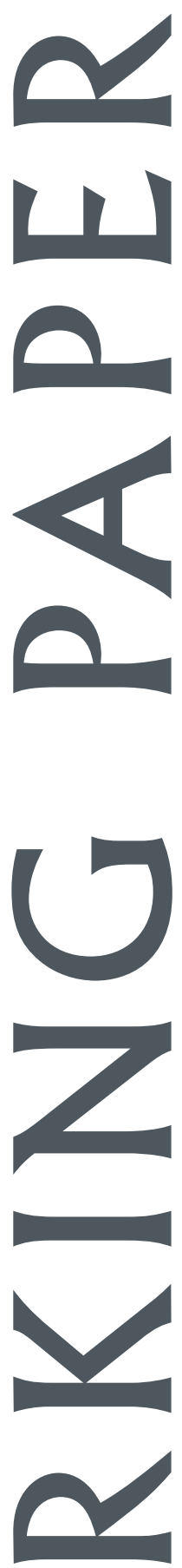

EAST-WEST CENTER 
The U.S. Congress established the East-West Center in 1960 to foster mutual understanding and cooperation among the governments and peoples of the Asia Pacific region including the United States. Funding for the Center comes from the U.S. government with additional support provided by private agencies, individuals, corporations, and Asian and Pacific governments.

East-West Center Working Papers are circulated for comment and to inform interested colleagues about work in progress at the Center.

For more information about the Center or to order publications, contact:

Publication Sales Office

East-West Center

1601 East-West Road

Honolulu, Hawaii 96848-1601

Telephone: 808-944-7145

Facsimile: 808-944-7376

Email: ewcbooks@EastWestCenter.org

Website: www.EastWestCenter.org 


\title{
What Do We Know About Carbon Taxes? An Inquiry into Their Impacts on Competitiveness and Distribution of Income
}

\author{
ZhongXiang Zhang and Andrea Baranzini
}

ZhongXiang Zhang is a Fellow in the Research Program at the East-West Center. He also is a part-time professor of economics at both the Chinese Academy of Social Sciences and Peking University, Beijing. He is the author of The Economics of Energy Policy in China: Implications for Global Climate Change (Edward Elgar, 1998) and co-author of International Rules for Greenhouse Gas Emissions Trading (United Nations, 1999). Currently, he is serving on the editorial boards of six international journals and one Chinese journal. He has also served as an expert/consultant to many national and international organizations. He has presented research findings in more than 25 countries over the past six years, and has been included in Marquis Who's Who in Science and Engineering and Who's Who in the World.

Andrea Baranzini is a professor of economics at Geneva School of Business Administration in Geneva, Switzerland.

East-West Center Working Papers: Environmental Change, Vulnerability, and Governance Series is an unreviewed and unedited prepublication series reporting on research in progress. The views expressed are those of the authors and not necessarily those of the Center. Please direct orders and requests to the East-West Center's Publication Sales Office. The price for Working Papers is $\$ 3.00$ each plus postage. To destinations within the U.S. and its territories: for surface mail, add $\$ 3.00$ for the first paper plus $\$ 0.75$ for each additional title or copy sent in the same shipment; for airmail add $\$ 4.00$ for the first paper plus $\$ 1.25$ for each additional title or copy in the same shipment. To destinations elsewhere: for surface mail, add $\$ 6.00$ for the first paper plus $\$ 1.50$ for each additional title or copy sent in the same shipment; for airmail, add $\$ 7.50$ for the first paper plus $\$ 3.50$ for each additional title or copy in the same shipment. 


\title{
What Do We Know About Carbon Taxes? \\ An Inquiry into their Impacts on Competitiveness and Distribution of Income
}

\author{
ZhongXiang Zhang* \\ Research Program \\ East-West Center \\ 1601 East-West Road \\ Honolulu, HI 96848-1601, USA \\ Tel: $+1-808-9447265$ \\ Fax:+1-808-944 7298 \\ Email: ZhangZ@EastWestCenter.org
}

\author{
Andrea Baranzini ** \\ Geneva School of Business Administration \\ Campus Battelle - unité F \\ 7 Route de Drize \\ CH-1227 Geneva \\ Switzerland
}

Tel: $+41-22-7059917$

Fax: $+41-22-7059998$

Email: Andrea.Baranzini@heg.ge.ch

\footnotetext{
* Fellow, Research Program, East-West Center, Honolulu, USA; Part-time Professor of Economics, at both Centre for Environment and Development, Chinese Academy of Social Sciences, Beijing, China and China Centre for Regional Economic Research, Peking University, Beijing, China.

** Professor of Economics, Geneva School of Business Administration, Geneva, Switzerland.
} 


\section{Abstract}

The Kyoto Protocol to the United Nations Framework Convention on Climate Change (UNFCCC) has set legally binding emissions targets for a basket of six greenhouse gases and timetables for industrialised countries. It has also incorporated three international flexibility mechanisms. However, the Articles defining the flexibility mechanisms carry wording that their use must be supplemental to domestic actions. This has led to the open debates on interpretations of these supplementarity provisions. Such debates ended at the resumed sixth Conference of the Parties (COP) to the UNFCCC, held in Bonn, July 2001, and at the subsequent COP-7 in Marrakesh, November 2001. The final wording in the Bonn Agreement, reaffirmed in the Marrakesh Accords, at least indicates that domestic policies will have an important role to play in meeting Annex B countries' emissions commitments. Carbon taxes have long been advocated because of their cost-effectiveness in achieving a given emissions reduction. In this paper, the main economic impacts of carbon taxes are assessed. Based on a review of empirical studies on existing carbon/energy taxes, it is concluded that competitive losses and distributive impacts are generally not significant and definitely less than often perceived. However, given the ultimate objective of the Framework Convention, future carbon taxes could have higher rates than those already imposed and thus the resulting economic impacts could be more acute. In this context, it has been shown that how to use the generated fiscal revenues will be of fundamental importance in determining the final economic impacts of carbon taxes. Finally, we briefly discuss carbon taxes in combination with other domestic and international instruments. 
JEL classification: Q25; Q28; Q43; Q48

Keywords: Border tax adjustments, carbon taxes, distribution of income, double dividend, emissions trading, energy taxes, international competitiveness

\section{Introduction}

The Kyoto Protocol to the United Nations Framework Convention on Climate Change (UNFCCC) has set legally binding reduction targets for greenhouse gases emissions to countries listed in its Annex B and introduced three international flexibility mechanisms, namely, international emissions trading, joint implementation, and the clean development mechanism (CDM). ${ }^{1}$ However, the Articles defining the flexibility mechanisms carry wording that their use must be supplemental to domestic actions. This is the so-called supplementarity provision. The European Union (EU) put forward a proposal for quantitative ceilings on the use of flexibility mechanisms (European Union, 1999), insisting that domestic abatement actions should be the main means of meeting emissions reductions required of each Annex B country (in other words, at least half of

\footnotetext{
${ }^{1}$ Annex B countries are the OECD countries and countries in transition to a market economy. The Kyoto Protocol includes six greenhouse gases: carbon dioxide $\left(\mathrm{CO}_{2}\right)$, methane $\left(\mathrm{CH}_{4}\right)$, nitrous oxide $\left(\mathrm{N}_{2} \mathrm{O}\right)$, sulfur hexafluoride $\left(\mathrm{SF}_{6}\right)$, perfluorocarbons (PFCs), and hydrofluorocarbons (HFCs). The Protocol will become effective once it is ratified by no less than $55 \%$ of the countries to the Convention whose $\mathrm{CO}_{2}$ emissions represent at least $55 \%$ of the total from Annex I countries in the year 1990.
} 
the emissions reductions required have to be undertaken domestically). ${ }^{2}$ With the US withdrawal from the Kyoto Protocol in March 2001, the EU dropped its previous insistence on a cap on the use of flexibility mechanisms to secure the reluctant support of other Umbrella Group ${ }^{3}$ members for the Protocol at the resumed sixth Conference of the Parties to the UNFCCC, held in Bonn, July 2001. The final wording in the Bonn Agreement, reaffirmed in the Marrakesh Accords, is now that "domestic action shall thus constitute a significant element of the effort made by each Party included in Annex I to meet its quantified emission limitation and reduction commitments". This at least indicates that domestic policies will have an important role to play in meeting Annex B countries' emissions commitments.

Article 2 of the Kyoto Protocol gives Annex B countries considerable flexibility in the choice of domestic policies to meet their emissions commitments. Possible policies include carbon/energy taxes, domestic emissions trading, command-and-control regulations and other policies. Economists and international organisations have long advocated carbon taxes, because they can achieve the same emissions reduction target at lower costs than conventional command-and-control regulations. Moreover, carbon taxes can act as a continuous incentive to search for cleaner technologies, while for commandand-control regulations there is no incentive for the polluters to go beyond the standards,

\footnotetext{
${ }^{2}$ See Zhang $(2000,2001)$ for detailed discussion on these supplementarity provisions and on the assessment of the EU proposal for ceilings on the use of Kyoto flexibility mechanisms.

${ }^{3}$ The Umbrella Group refers to the so-called JUSSCANNZ countries (Japan, the United States, Switzerland, Canada, Australia, Norway, New Zealand). It meets daily during the international climate change negotiations to exchange information and discuss substance/strategy on issues where there is common ground.
} 
unless the standards are continually revised and set slightly above the best available technologies (Zhang, 1997). In actual practice, only few European countries have already implemented taxes based in part on the carbon content of the energy products.

This paper assesses the empirical evidence of the main economic impacts of carbon taxes. Section 2 briefly compares carbon taxes with energy taxes. Section 3 discusses the treatment of carbon tax revenues. Sections 4 and 5 provide an assessment of the implications of carbon taxes for distribution of income and for international competitiveness, respectively. The paper ends with some concluding remarks.

\section{Energy taxes versus carbon taxes}

An energy tax is an excise tax, which is defined as a fixed absolute amount of, for example, US\$ per Terajoule, per British thermal units, or per kilowatt-hour. An energy tax is imposed on both fossil fuels and carbon free energy sources, according to their energy (or heat) contents, with renewables usually being exempted. By contrast, a carbon tax is an excise tax imposed according to the carbon content of fossil fuels and is thus restricted to carbon-based fuels only. ${ }^{4}$ Given that oil and gas have greater heat contents for a given amount of $\mathrm{CO}_{2}$ emissions as compared with coal, an energy tax lies more heavily on oil and gas than a carbon tax. Moreover, an energy tax burdens nuclear energy, which could provide large-scale generation of electricity without a directly parallel production of $\mathrm{CO}_{2}$ emissions. 
If the goal is to reduce $\mathrm{CO}_{2}$ emissions, a carbon tax is more cost-effective than an energy tax. Indeed, a carbon tax equalises the marginal cost of $\mathrm{CO}_{2}$ abatement across fuels and therefore satisfies the condition for minimising the global cost of reducing $\mathrm{CO}_{2}$ emissions. Therefore, the implementation of an energy tax will lead to poor $\mathrm{CO}_{2}$ target achievement or else to unnecessarily high costs as compared with a carbon tax (cf. Kågeson, 1991; Cline, 1992; Jorgenson and Wilcoxen, 1993b). This can be explained by two factors: price-induced energy conservation and fuel switching (Manne and Richels, 1993). Carbon taxes reduce $\mathrm{CO}_{2}$ emissions through both their price mechanism effects on energy consumption and fuel choice. By contrast, since the energy tax is imposed on fossil fuels and nuclear energy, the incentive for fuel switching is lower and the reductions in $\mathrm{CO}_{2}$ emissions will be mainly achieved by price-induced energy conservation. ${ }^{5}$ Thus, a higher energy tax is required for achieving the same reduction target as compared with a carbon tax. In other words, it is more costly to reduce $\mathrm{CO}_{2}$ emissions through an energy tax than through a carbon tax. This has clearly been shown by the study of Manne and Richels (1993), which evaluates the implications of the Commission of the European Communities' (CEC) proposal for a mixed carbon and energy tax. ${ }^{6}$ Similar findings are

${ }^{4} \mathrm{~A}$ carbon tax can be translated into a $\mathrm{CO}_{2}$ tax , since a ton of carbon corresponds to 3.67 tons of $\mathrm{CO}_{2}$.

${ }^{5}$ Of course, in environmental terms there could be good reasons for also discouraging the use of nuclear energy. In this case, contrary to a carbon tax, an energy tax will give a greater incentive to switch to renewable energy.

${ }^{6}$ Recognising that a carbon tax puts a relatively high pressure on coal, the most secure energy supply, and that both a carbon tax and an energy tax have a quite different impact on member states, a carbon/energy tax was proposed by the CEC as part of its comprehensive strategy to control $\mathrm{CO}_{2}$ emissions and increase energy efficiency. The $\mathrm{CEC}$ proposal 
also found in other studies by Jorgenson and Wilcoxen (1993b) and Beauséjour et al. (1995). The results of Jorgenson and Wilcoxen suggest that, in 2020, the US GNP loss from an energy tax will be $20 \%$ greater than that resulting from a carbon tax in order to stabilise the US $\mathrm{CO}_{2}$ emissions at 1990 levels in that year. The results of Beauséjour et al. indicate that, in 2000, Canada's GDP loss from an energy tax will be $20 \%$ greater than that resulting from a carbon tax in order to stabilise Canada's $\mathrm{CO}_{2}$ emissions at 1990 levels in that year. While being more cost-effective, the carbon tax is also less burdensome, since it raises a smaller amount of government revenues for a given reduction of $\mathrm{CO}_{2}$ emissions (Jorgenson and Wilcoxen, 1993b; Beauséjour et al., 1995).

Let us now focus in some detail on the carbon tax. So far, a number of studies have focused on the cost estimates for achieving a given reduction in $\mathrm{CO}_{2}$ emissions. These studies usually incorporate a carbon tax as an instrument to achieve the target because of its cost-effectiveness. The main findings arising from these studies are that, among other things:

- The carbon tax rate should increase over time if it has to reflect the rising costs of damages from the accumulation of $\mathrm{CO}_{2}$ concentration in the atmosphere; if it has to give the markets the signal that $\mathrm{CO}_{2}$ emissions will eventually be heavily taxed; and if there are few economically feasible substitutes available. This signal strengthens

was that member states introduce a carbon/energy tax of US\$ 3 per barrel oil equivalent in 1993 , rising in real terms by US\$ 1 a year to US\$ 10 per barrel in 2000. After the year 2000 , the tax rate will remain at US\$ 10 per barrel at 1993 prices. The tax rates are allocated across fuels, with $50 \%$ based on carbon content and $50 \%$ on energy content (cf. CEC, 1991). 
the incentive for technical innovation needed to make more stringent future emissions targets affordable; ${ }^{7}$

- There would be significant variation in timing and size of the carbon taxes among countries and regions, given that the marginal cost of abating $\mathrm{CO}_{2}$ emissions substantially differs across countries and over time;

- The autonomous (that is, non-price-induced) energy efficiency improvement, the possibilities for fuel substitution, and the availability of backstop technologies are essential elements in determining the evolution of the tax rate over time. Without non-fossil fuel options, the upper bound on the required carbon tax rate would rise. The autonomous energy efficiency improvement and the cost and availability of lowcarbon or carbon-free backstop technologies are crucial to limit the tax rate required and thus reducing the costs incurred for compliance with emission reduction targets; ${ }^{8}$

- The carbon tax could be production- or consumption-based, but the effects across options would be significantly different among countries. A national productionbased carbon tax operates much like an export tax. If applied, oil-exporting countries such as OPEC would gain substantially, because the revenues generated from such a production tax accrue to countries proportional to their own production. On the

\footnotetext{
${ }^{7}$ In addition, in the presence of inflation, the tax rate has to be indexed to keep the price signal constant in real terms.

${ }^{8}$ As assumed in the GREEN model, the backstop technologies are produced at a constant marginal cost, without any constraint on supply (cf. Burniaux et al., 1992). Thus, the carbon tax rate needs not to increase further than that level. If there are few economically feasible substitutes available, however, the effectiveness of a carbon tax is likely to be much more limited. Thus, to lower $\mathrm{CO}_{2}$ emissions very substantially would require a high carbon tax - certainly higher than the taxes already imposed (Barrett, 1991).
} 
contrary, a national consumption-based tax acts somewhat like an import tariff. In that case, oil-exporting countries would suffer considerably, because the revenues generated from such a consumption tax accrue to countries proportional to their consumption (Whalley, 1991; Whalley and Wigle, 1991a, 1991b);

- Carbon taxes imposed unilaterally or even regionally would be largely ineffective (cf. Pezzey, 1992; Felder and Rutherford, 1993). This ineffectiveness is attributed partly to the relatively small share of the coalition (for example, EU, OECD) emissions in the world total, and partly to the strong economic growth and the resulting increase in emissions taking place in non-coalition countries that offset the coalition's achievements; ${ }^{9}$ and

- The carbon tax itself would impose a deadweight loss on a country where there are no distortions in the energy markets. However, when existing distortions arising from energy subsidies are taken into account or when the revenues generated from the imposition of a carbon tax are recycled to the economy for reducing a distortionary tax, the introduction of a carbon tax could even lead to a net gain. ${ }^{10}$

The remainder of the paper will not go into these interesting topics any further, but instead will focus on three aspects that are considered important when designing a domestic

\footnotetext{
${ }^{9}$ This is the so-called 'carbon leakage' phenomenon, with its average leakage rate being defined as the ratio of carbon emission increase outside the coalition to carbon emission cutbacks within the coalition relative to their reference levels (cf. Felder and Rutherford, 1993).

${ }^{10}$ For example, the results based on the GREEN model clearly indicate the net gains for Eastern Europe and the former Soviet Union if the existing energy subsidies are taken into account. See also in the next section the discussion on the 'double dividend' issue.
} 
carbon tax, namely, (i) the treatment of the carbon tax revenues, (ii) the impacts on the distribution of income, and (iii) the effects on international competitiveness.

\section{The treatment of the carbon tax revenues}

Let us begin with the treatment of the carbon tax revenues. It has been argued that there is a 'double dividend' from the carbon tax (Pearce, 1991): not only an environmental dividend through reduced emissions of pollutants (i.e., a reduction in $\mathrm{CO}_{2}$ and other pollutants associated with fossil fuels combustion), but also an additional dividend in terms of a reduction in the overall economic cost of raising government revenues (Lee and Misiolek, 1986; Feldstein, 1999). ${ }^{11}$ In the literature, the weak 'double dividend' and the strong 'double dividend' are distinguished (see Goulder, 1995).

The weak 'double dividend' proposition states that, in welfare terms, the nonenvironmental dividend is always positive, as a reduction in distortionary taxes is always superior to a reduction of lump-sum taxes. In other words, costs savings may be achieved by using carbon taxes revenues to reduce distortionary taxes, with respect to the case where tax revenues are returned in a lump-sum way. The magnitude of the potential cost savings

11 The non-environmental dividend is very often interpreted as using the extra carbon tax revenues to reduce existing distortionary taxes for raising government revenues. This dividend can of course have other interpretations. In the study of Bovenberg (1994), for instance, reduced unemployment is referred to as the potential extra dividend in addition to improved environmental quality. In the context of tradeable carbon permits, the extra dividend refers to the proceeds from the sale of carbon emission permits (Manne and Richels, 1995). 
depends on each country's particular economic circumstances. For instance, in the US economy, as indicated in Bovenberg and Goulder (1996), capital is overtaxed with respect to labour. In this case, using carbon taxes revenues to correct taxation towards lower taxes on capital may produce higher cost savings than reducing labour taxes.

The strong 'double dividend' proposition states that the non-environmental dividend is larger than the gross costs. In this case, it would mean that 'green tax swaps' could be costless to introduce, because they yield a net welfare gain (or a higher GDP or employment). In the literature, there are, however, ambiguities as to whether the strong economic double dividend hypothesis can be accepted or has to be rejected. On the one hand, results from some empirical studies (cf. Ekins 1998, EC 1997, Barker 1995, Bach et al., 1994) show that an improvement in the environmental quality can be accompanied by a simultaneous increase in employment. On the other hand, other studies seem to reject the hypothesis (e.g., Bovenberg and Goulder, 1996), at least when the initial tax system is relatively efficient. Such results are pointed out when considering the interaction of carbon taxes with the existing tax system. Indeed, the existence of an economic double dividend depends on two effects (see Parry, 1997). First, since carbon taxes add to existing distortionary taxes (e.g., on labour and capital), they may further reduce overall employment and investment. This is what is called the 'tax-interaction' effect, which raises the costs of reducing carbon emissions. Second, carbon taxes revenues may be used to reduce the level of distortionary taxes, thus producing an economic gain (called the 'revenue-recycling' effect). The overall cost of carbon taxes depends on the relative weight of the previous two effects and is thus mainly an empirical issue. If the welfare gain from the revenue-recycling effect is higher than the welfare costs from the tax-interaction effect, 
then there is an economic net benefit (i.e., a strong economic 'double dividend') from carbon taxes.

It should however be emphasised that, by accounting for pre-existing distortionary taxes, revenue-raising instruments result in even higher costs savings, with respect to command-and-control (or freely distributed permits) approach. For instance, Parry, Williams and Goulder (1999) have showed that the costs of reducing U.S. $\mathrm{CO}_{2}$ emissions by $10 \%$ in a second-best setting with pre-existing labour taxes are five times higher under a grandfathered carbon permits case than under a carbon tax (or under an auctioned case). As explained above, the much higher economic costs in the former case reflect the inability of the command-and-control policy to generate revenues that can be used to reduce pre-existing distortionary taxes.

Of course, this 'double dividend' feature of a carbon tax has important implications for 'green tax swaps' for distortionary taxes, because different taxes have different distortionary effects on the economy. To minimise the impact on the general level of prices, revenues raised through an increase in one indirect tax (the carbon tax) could be offset by a reduction of another indirect tax, for example value added tax (VAT). ${ }^{12}$ This has been confirmed by several studies (e.g., DRI (1991), Standaert (1992), and Barker et al. (1993)), the results of which show that reducing VAT offsets the carbon tax's inflation impact more than using the carbon tax fiscal revenues to decrease other taxes. The studies of Karadeloglou (1992) and Standaert (1992) also show that the effects in the case of reducing VAT on both GDP and employment are less negative than those in other tax offset cases.

\footnotetext{
${ }^{12}$ A carbon tax, by raising the prices of fossil fuels, will raise the general level of prices. Offsetting it with reductions in VAT or other taxes tends to lower the price level, but the price effect is expected to vary, depending on the tax offset arrangements.
} 
Another measure used to recycle all revenues from the carbon tax back to the economy is by means of reducing income tax. However, in this case inflation is likely to increase, although the extent of acceleration depends on the character of wage negotiations for increases in disposable income resulting from the reduction in income tax. This higher inflationary response has been found in the modelling of the effects of the CEC tax (cf. DRI, 1991; Karadeloglou, 1992; Standaert, 1992; Barker et al., 1993). Alternatively, if the carbon tax revenues are retained in treasury coffers to reduce public sector deficits, then this could depress the economy. If the revenues were all spent by the government, for example on non-fossil energy investment, this would imply a large investment programme which could lead to rapid inflation (Barker et al., 1993).

\section{Distributive implications}

The impact of a domestic carbon tax on the distribution of income is a fundamental factor determining its acceptability (cf. Baranzini, 1997). Since lower income households spend a larger proportion of their income on energy than higher income households do, a carbon tax is expected to have a regressive impact on the distribution of income. For example, Smith (1992) calculates the distributional effects on different income groups of a mixed carbon and energy tax at $\$ 10$ per barrel in the UK. The results show that the poorest $20 \%$ of the population would have to pay an additional tax of $£ 1.45$ per week, the richest $20 \%$ an additional $£ 2.95$ per week, and the average household an additional $£ 2.21$ per week. Translated into increases of tax paid as a percentage of total spending, these figures 
are equivalent to $2.4 \%, 0.8 \%$ and $1.4 \%$, respectively. Clearly, the relative burden of the additional tax would be heavier for the poorest decile and lower for the richest. Similar findings are also shown by the study of Poterba (1991), the results of which show that, if the US imposed a tax of $\$ 100$ per ton of carbon, the tax burden would amount to $10 \%$ of income for the lowest income group, whereas the corresponding figure would amount only to $1.5 \%$ for the highest income group.

However, there are a number of studies that show that the distributive impacts are relatively weak. A review of the literature on this topic by Speck (1999) shows that, although carbon or energy taxes are regressive, the impacts on low-income households are relatively moderate, depending on the type of fuel being taxed (heating, transport), but also on the distribution of benefits from improved environment quality among the population. In the studies where energy products are distinguished between domestic energy (e.g., energy used for heating, cooking, lighting, etc.) and transport fuels, it appears that the overall weak regressive effect of carbon taxes is due to taxes on domestic energy, because the taxation of transport fuels has a weakly progressive outcome for most EU countries (Barker and Köhler, 1998). Nevertheless, even if the distributive impacts are relatively small, the distributive argument against carbon taxes is intense, probably because the costs associated with other instruments (e.g., regulations) can be easily hidden from the general public, whereas the introduction of a carbon tax is more directly perceived with an increase in prices. ${ }^{13}$ Recent history in developed countries' fiscal

\footnotetext{
${ }^{13}$ Unfortunately, there are relatively few studies on the distributional impacts in developing countries. Shah and Larsen (1992) argue that the results in developed countries cannot be generalized for the developing countries, where the incidence of carbon taxes would be affected by institutional factors. Among some important factors that may have a bearing on tax-shifting are market power, price controls, import quotas, rationed foreign exchange, the
} 
policies suggests that there is great resistance to the introduction of taxes that fall on the poor (cf. Poterba, 1991). Thus, if public support for the imposition of carbon taxes is to be secured, their possible regressive distributional impacts warrant serious political attention in the design of the tax. ${ }^{14}$ There are different options to mitigate the potential regressive impacts of a carbon tax.

One way to mitigate the regressive distributional impacts is to set a tax-free allowance for essential use of energy. For instance, energy - in particular metered domestic energy - could be taxed only above a certain floor, so that each household has a tax free energy allowance. The idea is that some amount of energy is necessary to satisfy basic needs. Above that floor, energy would be progressively taxed to provide the incentive for reducing energy consumption. Such a scheme is already implemented in the Dutch regulatory energy tax on small energy users. The tax introduced in January 1996 was designed with special consideration given to distributional concerns. It has set a taxfree allowance of $800 \mathrm{~m}^{3}$ per year for gas and of $800 \mathrm{kWh}$ for electricity to reduce its distributional effect on lower income groups (Alblas, 1997).

The other ways to decrease the regressive impacts of energy/carbon taxes are through the use of the generated fiscal revenues. One possibility is by means of ex post lump-sum redistribution of carbon tax revenues to population. Such a scheme would mitigate regressive distributional impacts, because the lowest income groups will proportionally receive a higher amount, relative to their income, than highest income

presence of black markets and tax evasion, and urban-rural migration (see Shah and Larsen (1992) for a further discussion). 
households will do. However, using the carbon tax revenues in this way will reduce the scope for the revenues to be used to maximise the efficiency gains from reductions in other existing distortionary taxes, and could probably lead to negative effects on macroeconomic variables, such as inflation and employment. Another possibility to compensate poorer households suffering from the tax is by using the generated fiscal revenues to reduce labour taxes, decrease income taxation, or change the social security system, such as an increase in housing benefits and social benefits based on means-tested benefits. Those options can have a better outcome in terms of mitigating distributional effects than lump-sum redistribution. However, such measures should be accompanied by a complementary redistribution policy that targets those social groups that do not benefit directly from such tax cuts, such as pensioners and the unemployed.

All this highlights the fact that unless low income groups are to be made worse off by the carbon tax, a part of the revenues from the tax will need to be used to compensate poorer households suffering from the tax, e.g., by lump-sum redistribution, through tax reductions, or increases in social security benefits and pensions. Unfortunately, using the carbon tax revenues in this way will reduce the scope for the revenues to be used to maximise the efficiency gains from reductions in other existing distortionary taxes, for example, VAT described above (cf. Barker, 1992; Pearce, 1991). Thus, there is a clear trade-off between efficiency and equity in the use of the revenues: the efficiency gains can only be achieved by sacrificing the distributional neutrality of the package (Smith, 1992). We should however note that, from an acceptability point of view, it seems that the way

${ }^{14}$ Ekins (1999) believes for instance that the inability of the British government in 1994 to raise VAT on domestic fuel from $8 \%$ to $17.5 \%$ was at least due partly to concerns about its impacts on the poor. 
energy/carbon taxes fiscal revenues are redistributed does not matter that much, as shown in a recent empirical study by Thalmann (2001). The study analyses the results of the vote of the Swiss citizens on three different energy tax proposals, which differed mainly on the mode of revenue recycling. The three proposals were rejected and Thalmann (2001) shows that for most voters the mode of revenue recycling did not matter. Those who distinguished the taxes favoured the smaller tax whose revenues were dedicated to subsidies for the greatest number of different uses, but individual approval depended foremost on political preferences and general confidence in government.

\section{International competitiveness}

A domestic carbon/energy tax has potentially important implications for the international competitiveness of economies in relative terms. Although international competitiveness is not necessarily reduced over the long term by higher energy prices, in certain industries the effects of a unilateral carbon tax may be serious in the short term. This issue has become the main stumbling block for the introduction of energy/carbon taxes (Barde, 1997), and thus has been a constant concern to policymakers.

Competitiveness at the firm level is the ability of a firm to maintain or even increase international or domestic market shares and profitability. A firm' competitiveness is influenced both by 'micro' factors, such as cost structure, product quality, trademark, service and logistical networks, and by 'macro' factors, such as exchange rates, trade rules and political regime stability (Baron and ECON-Energy, 1997). A carbon/energy tax affects 
a firm's competitiveness by changing its relative production costs. For example, if a firm makes intensive use of energy, ceteris paribus, then imposing a carbon/energy tax will increase its production cost relative to those less energy-intensive firms in the short term. Thus, it would experience a decline in competitiveness, whereas less energy-intensive firms would obtain a relative cost advantage in the short term. The changes in relative competitive positions would lead to 'winners' as well as 'losers' from the imposition of carbon/energy tax. Not surprisingly, 'losers' lobby strongly against the imposition of carbon/energy taxes. They even threaten to relocate their business activities to those countries that have relatively lax environmental standards, if such a tax were put in place. This raises the question: do environmental taxes and regulations hurt firms' competitiveness so badly that they are forced to move to pollution havens? There is growing literature on this topic, and the existing studies on trade implications of environmental regulations might give us some indications.

Grossman and Krueger (1993), for example, have examined whether pollution abatement costs influenced the patterns of the U.S. bilateral trade and investment with Mexico and found that "the available evidence does not support the hypothesis that crosscountry differences in environmental standards are an important determinant of the global patterns of international trade." Jaffe et al. (1995) review and analyse over 100 studies on the potential effects of environmental regulations on the competitiveness of American industry, and conclude that "studies attempting to measure the effect of environmental regulation on net exports, overall trade flows, and plant-location decisions have produced estimates that are either small, statistically insignificant or not robust to tests of model specification.”. The Annex I Expert Group on the UNFCCC (Baron and ECON-Energy, 
1997) undertook a static analysis of the cost increases from a tax of $\$ 100$ per ton of carbon on four energy-intensive industries (iron and steel, non-ferrous metals, paper and pulp, and chemical products) in the OECD countries. These sectors represent 3 to $7 \%$ of GDP and 1 to $4 \%$ of labour force. As shown in Table 1, the average cost increase measured as percentage of total production value differs among countries and sectors, but is generally relatively low (below 2\%) except for Australia and Canada. This analysis concludes that other factors affecting price levels, such as exchange rate variations, may well dwarf the price effects of a carbon tax, at least at the rates that are generally proposed in the current climate debates.

Table 1 Selected OECD countries' cost increase ${ }^{\mathrm{a}}$ from a tax of $\$ 100$ per ton of carbon as percentage of production value

\begin{tabular}{|l|c|c|c|c|c|}
\hline & $\begin{array}{c}\text { Total } \\
\text { energy- } \\
\text { intensive } \\
\text { industries }\end{array}$ & $\begin{array}{c}\text { Iron and } \\
\text { steel }\end{array}$ & $\begin{array}{c}\text { Non-ferrous } \\
\text { metals }\end{array}$ & $\begin{array}{c}\text { Chemical } \\
\text { products }\end{array}$ & $\begin{array}{c}\text { Pulp and } \\
\text { paper }\end{array}$ \\
\hline USA & $2.8(2.5)$ & 2.3 & 3.1 & $2.8(2.2)$ & 3.2 \\
Canada & $4.1(4.3)$ & 6.2 & 3.7 & $4.1(2.3)$ & 5.0 \\
Japan & $1.2(1.0)$ & 2.0 & 0.7 & $1.0(0.6)$ & 0.6 \\
Australia & $5.2(5.0)$ & 5.8 & 11.4 & $1.7(1.4)$ & 2.6 \\
France & $1.4(1.1)$ & 2.4 & 1.4 & $1.3(0.8)$ & 0.6 \\
Germany & $1.6(1.4)$ & 2.6 & 1.2 & $1.4(1.1)$ & 1.0 \\
UK & $1.6(1.3)$ & 3.6 & 1.9 & $1.2(0.8)$ & 1.2 \\
Italy & $1.4(1.2)$ & 2.0 & 1.1 & $1.3(0.9)$ & 0.7 \\
Belgium & $2.3(2.1)$ & 7.3 & 0.8 & $1.6(1.2)$ & 0.6 \\
\hline
\end{tabular}

${ }^{a}$ The figures include carbon emissions through electricity generation and from process emissions in aluminium production.

Numbers in parentheses indicate cost increase when the carbon tax is applied only to fossil fuels used for energy purposes.

Source: Baron and ECON-Energy, 1997.

Concerning industrial relocation, there is some evidence that some energyintensive national and multinational firms (e.g., oil refining, aluminium, and cement) 
have chosen to shift investment and production to other countries, especially to developing countries. OECD (1993) indicates that the firms more likely to reinvest abroad or shut down capacity are those in sectors suffering competitive difficulties due to overall economic conditions and where environmental costs are a high share of new investment costs. ${ }^{15}$ Trade liberalisation among countries with different environmental policies could also increase relocation (see Hudson (1993) in the context of the North American Free Trade Agreement). However, uncertainties over future environmental standards may impede foreign investment and decrease predisposition to relocate (see Zamparutti and Klavens (1993) for Eastern European countries).

However, the above findings are not necessarily going to be the case of energy/carbon taxes in the future. Indeed, environmental regulations and taxes applied to date have been relatively modest, and they fall short of the levels required to achieve the UNFCCC's ultimate objective of stabilising greenhouse gas concentrations in the atmosphere at a level that would prevent dangerous anthropogenic interference with the climate system. For example, if carbon taxes were used as the sole means of meeting the Kyoto emissions obligations, the level of the taxes would be very high and could thus have significant implications for competitiveness. However, since all industrial countries will have to reduce emissions under the Kyoto Protocol, industries in different countries will almost simultaneously experience an increase in their costs. In this case, a country implementing a carbon tax and depending on the recycling of fiscal revenues could increase the competitiveness of its industries, compared to other countries implementing less cost-effective instruments, like e.g., regulations.

${ }^{15}$ Data on plant closures because of tight environmental regulations are difficult to find 
Table 2 Effective and nominal tax rates (1998) in selected sectors in Sweden, Denmark and Norway (ECU per ton of $\mathrm{CO}_{2}$ emissions, $1 \mathrm{ECU}=\mathrm{US} \$ 1.12$ )

\begin{tabular}{|l|c|c|c|c|}
\hline \multirow{2}{*}{$\begin{array}{c}\text { Energy } \\
\text { products }\end{array}$} & $\begin{array}{c}\text { Sweden } \\
\text { (nominal) }\end{array}$ & \multicolumn{2}{|c|}{$\begin{array}{c}\text { Denmark } \\
\text { (nominal) }\end{array}$} & $\begin{array}{c}\text { Norway } \\
\text { (nominal) }\end{array}$ \\
\cline { 2 - 5 } & $\begin{array}{c}\text { Manufacturing } \\
\text { industry }\end{array}$ & $\begin{array}{c}\text { Light } \\
\text { processes }\end{array}$ & $\begin{array}{c}\text { Heavy } \\
\text { processes }\end{array}$ & Pulp/paper industry \\
\hline Gas oil & 20.9 & 11.2 & 3.1 & 9.9 \\
(heating) & $(41.9)$ & $(12.5)$ & $(12.5)$ & $(19.9)$ \\
\hline Heavy fuel oil & 18.8 & 11.6 & 3.2 & 8.8 \\
& $(37.7)$ & $(12.8)$ & $(12.8)$ & $(17.6)$ \\
\hline LPG & 20.2 & 11.5 & 3.2 & 0 \\
& $(40.4)$ & $(12.8)$ & $(12.8)$ & 23.4 \\
\hline Coal & 21.5 & 11.9 & 3.3 & $(23.4)$ \\
& $(43)$ & $(13.2)$ & $(13.2)$ & 0 \\
\hline Natural gas & 19.3 & 11.3 & 3.1 & $(12.5)$ \\
& $(38.5)$ & $(12.5)$ & $(48.8)$ \\
\hline
\end{tabular}

Source: Adapted from EC (1999).

The potentially high energy/carbon taxes underline the importance to mitigate their competitiveness effects in designing the taxes. One commonly used way is to grant energy-intensive industries a lower tax rate than, e.g. households, or even to exempt these industries from coverage of the taxes. For example, the unimplemented CEC proposal provided for exemptions for the six energy-intensive industries, such as iron and steel, nonferrous metals, chemicals, cement, glass, and pulp and paper. In countries such as Denmark, Norway and Sweden, where carbon/energy taxes are already implemented, (see Sprenger (1998) for Germany). 
energy-intensive industries are generally exempted from the taxes, either totally or partially (which leads to a large gap between effective and nominal tax rates as shown in Table 2). If not totally exempted, the revenues from environmental taxes are often fully recycled back to the affected industries, for example in the form of grants for energy saving investments and cuts in employers' social security contributions (cf. Baranzini et al., 2000).

However, since a carbon tax is intended to fall most heavily on the products of carbon-intensive industries, the exclusion of these industries from coverage of the carbon tax on the grounds of competitiveness reduces the effectiveness of the carbon tax in achieving its objective of reducing $\mathrm{CO}_{2}$ emissions. ${ }^{16}$ As demonstrated in the study of Bruvoll and Larsen (2003), although the carbon tax implemented in Norway reached as high as US\$51 per ton of $\mathrm{CO}_{2}$ in 1999 , exempting those sectors where the carbon tax would have been otherwise effective only led to the modest reduction in emissions of $2.3 \%$ in comparison with no carbon tax case. Moreover, such exemptions require a higher tax rate for the nonexempt industries and thus increase the costs of achieving a given level of emissions reduction. For instance, Böhringer and Rutherford (1997) found that losses associated with exemptions can be substantial, even when the share of exempted sectors in overall

\footnotetext{
${ }^{16}$ In addition to this, exemptions lead to two more problems. The first is that the industries, which are exempt from paying the carbon tax, will improve their competitive position in relation to those industries which are not. There will therefore be some switching of demand towards the products of these energy-intensive industries, which is precisely the reaction that a carbon tax should avoid. The other problem is that firms which find themselves paying the carbon tax will try to be reclassified as exempt or eligible for rebates if at all possible, thus limiting the impact of the tax on energy consumption and $\mathrm{CO}_{2}$ emissions (cf. Barker et al., 1993).
} 
economic activity and carbon emissions is small. Alternative recycling options, like wage subsidies to export- and energy-intensive sectors, can give better results in terms of employment and are less costly than tax exemptions. However, removing exemptions could be relatively costly for those sectors that benefit from them. For instance, Godal and Holtsmark (1998) estimate that removing exemptions in the Norwegian $\mathrm{CO}_{2}$ tax regime and replacing them by a uniform $\mathrm{CO}_{2}$ tax on all $\mathrm{CO}_{2}$ emissions would decrease profits in the emission-intensive industry by $18 \%$.

Another means of mitigating competitiveness effects is through border tax adjustments (BTAs), whereby exporting countries rebate taxes levied on the products when exported, while the importing countries impose the taxes on imported products that have not been subjected to a similar level of taxes levied on their domestic products. The adjustments enable a country to tax its domestic energy-consuming industries for internal purposes while preserving its competitiveness internationally by allowing its exports to compete in untaxed markets abroad and domestically by taxing imports up to the same level. This kind of BTAs reflects the application of the destination principle to products: products should be taxed in the country where they are consumed and not in the country where they are produced, unless they are also consumed there. Clearly, such adjustments are intended to ensure that internal taxes on products are trade-neutral. BTAs have been used in the US in two important instances of environmental excise taxes: the Superfund Chemical Exercises (Superfund Tax) and the Ozone-Depleting Chemicals (ODC) Tax. With a modest rate of $\$ 4.87$ per ton, the Superfund Tax was designed to place the burden of such cleanup on those responsible for generating the wastes, but was not intended to influence behaviour through the price system. On the other hand, the ODC Tax aimed to 
harness market forces in finding substitutes for the taxed chemicals, which turned out to be effective both in raising the price of taxed chemicals and in discouraging their production (Hoerner, 1998).

When considering BTAs for energy/carbon taxes, it is necessary to distinguish energy products (e.g., coal, oil, and gas) from final products (e.g., cars, chemical products). As it would be expected, the application of BTAs to energy products is relatively straightforward. The GATT/WTO rules allow the same taxes to be imposed on imported-like (energy) products and the rebate of indirect taxes on exported domestic products, as long as there is no discrimination against foreign energy products. However, the situation becomes much more complicated when the products to be imported or exported are not the energy products themselves, but goods whose production or distribution involve the use of taxed energy inputs. Let alone whether the process-based BTAs are in conflict with the GATT/WTO principles (see, for example, Stewardson (1994); Brack et al. (1999)), there are formidable technical difficulties, if not entirely impossibilitiesle, in identifying the appropriate energy/carbon contents embodied in virtually all traded products, unless exporting countries that do not impose energy/carbon taxes are willing to cooperate in certifying how the products are produced.${ }^{17}$ In the absence

17 The use of a de minimis floor could substantially reduce the number of products that would be covered in the case of energy/carbon taxes, so that BTAs should be avoided where the tax is trivial percentage of the price. For example, in the case of the above Superfund Tax, BTAs are limited to primary products for which the share of taxable chemicals in production is at least 50\%, while in the case of the ODC Tax a de minimis rule is applied to non-listed products (Hoerner, 1998). However, the desirability of the use of a de minimis floor to lower substantial administrative burden must be weighted against the environmental effectiveness of energy/carbon taxes. 
of any information regarding the carbon content of the products from exporting countries, importing countries could for instance prescribe the tax rates based on their domestically predominant method of production for the imported products. This practice is by no means without foundation. For example, the US Secretary of the Treasury has adopted the approach in the tax on imported toxic chemicals under the Superfund Tax (Poterba and Rotemberg, 1995; Hoerner, 1998). Such a practice seems very hard to justify in the case of energy/carbon taxes, given the wide range of technologies in use around the world and very different energy resource endowments and consumption patterns among countries. Even if the same technology were used to produce the same products among countries, the differing resource endowments could lead to a sharp difference in the energy consumption of their most economically efficient technology. For a country that relies on coal as its major source of energy, the larger amount of energy used by a coal-based technology per unit of output vis-à-vis oil/gas-based technologies occurs partly as a result of its high proportion of coal consumption, because coal-based technologies are less efficient than oil/gas-based technologies (Zhang, 1997). It seems unfair to penalise the country whose energy consumption is coal-dominant, just because it is unfortunate to have less endowments of oil/gas that, if burned, emits less carbon that coal. Moreover, such a practice would violate the WTO rules that do not allow to take trade measures on the basis of the differences in process and production methods (PPM), and appear to deprive developing countries of enjoying the very basis of comparative advantage in their production. Furthermore, such tariffs would likely violate commitments made by the WTO contracting countries not to raise import taxes above 'bound tariff' levels, i.e., maximum tariffs for goods listed in an annex to the GATT (WTO, 1995). 
The potential effects on competitiveness can also be attenuated if the introduction of energy/carbon taxes is announced in advance, phased-in gradually and increased over time. This will help to reduce economic effects of the tax by avoiding unduly early retirements of existing infrastructures and, at the same time, send a steady but strong price signal for a shift away from carbon-intensive choices. For example, the above ODC Tax in the US was phased-in gradually over a period of years. For the most important ODCs, the Tax is currently more than five times the ex-tax price (Hoerner, 1998).

Of course, another means of mitigating competitiveness effects would be through the international harmonisation of energy/carbon taxes. Up to now, our discussion has been restricted to a domestic carbon tax, which is an efficient way to achieve a domestic emission target. However, even if domestic emission reduction targets are achieved in costefficient ways, a global cost-efficient emission reduction target can only be achieved if $\mathrm{CO}_{2}$ emissions are distributed among countries in such a way that the marginal cost of abatement is equalised among countries (cf. Hoel, 1991, 1992). Global cost efficiency may be achieved through either an international carbon tax or a tradeable carbon emission permits regime. Hoel (1991) has shown that a tax administrated and collected by an international agency would be too bureaucratic and would interfere with domestic sovereignty, while a tax implemented by each government would fall foul of free rider problems, since governments could easily offset a carbon tax by reducing other domestic taxes on fossil fuels. The way out could be one in which the carbon tax is globally imposed on each country by some international agency, but nationally administrated and collected through its central government (cf. Hoel, 1991). The carbon tax would be set to be the same for each country. The revenues from the tax would then be reimbursed and handed back to 
the countries where the revenues are raised according to some agreed rule of allocation. Each country would then act to minimise the sum of its tax payments and abatement costs. Moreover, if an international carbon tax could be put in place, it will help avoid applying complex border tax adjustments among the countries where the common tax is imposed.

However, the international harmonisation of energy/carbon taxes is faced with some fundamental problems. For instance, the above mentioned CEC proposal for harmonisation at the EU level failed to gain the unanimous support of its member states, mainly because some member states (e.g., the UK) opposed an increase in the fiscal competence of the European Community and thus opposed the introduction at a EU level of a new tax on the grounds of fiscal sovereignty (Delbeke, 1997; Bill, 1999). Even if it had been agreed at the EU level, competitiveness concerns from the outside of the EU suggest that at least similar actions in other main OECD competitors, especially in the United States and Japan, should be undertaken (or some more general OECD-wide tax should be adopted), although it is ideal to impose carbon taxes globally in order to achieve sufficient reductions in global $\mathrm{CO}_{2}$ emissions. However, given the political difficulties of introducing carbon taxes in countries such as the US, the prospects for the harmonisation of carbon taxes at the OECD level seem remote, let alone across wider group of countries. Moreover, the initial difference in energy prices further complicates the harmonisation of carbon tax (Zhang, 1997; Eizenstat, 1998). As a consequence of existing distortions in price regulations, taxation, national monopolies, barriers to trade and so on, there are initially great differences in energy prices, both between fuels and across 
countries (cf. Hoeller and Coppel, 1992) ${ }^{18}$ If $\mathrm{CO}_{2}$ emissions are then to be reduced by similar amounts in two countries, ceteris paribus, lower taxes are required for the country with low prices before the tax imposition than for the country with the higher pre-tax prices. Thus, an eventual cost-efficient regime of international carbon tax would presumably need to remove existing distortions in international energy markets. Otherwise, countries with lower pre-tax prices would enjoy free rider benefits, whereas countries with higher pre-tax prices would attempt to offset the impact of international carbon tax through other changes in tax and subsidy policies. In the latter case, distinguishing permissible from prohibited policies would be extraordinarily difficult and could bring unacceptable international scrutiny to domestic tax decisions (Eizenstat, 1998).

Thus, it follows that while the harmonisation of energy/carbon taxes at the OECD and global levels seems to be theoretically the ideal solution, it is hardly a practical solution to mitigating competitiveness effects.

\section{Conclusions}

The Kyoto Protocol to the United Nations Framework Convention on Climate Change is the first international environmental agreement that sets legally binding emissions targets for a basket of six greenhouse gases and timetables for Annex B countries. To fulfil their emissions reduction commitments, Annex B countries will need

\footnotetext{
${ }^{18}$ For instance, based on computations made by Hoeller and Coppel (1992), the average implicit carbon tax in 1988 in Purchasing Power Parity (PPP)/ton of carbon is US\$ 302 in Switzerland, and only US\$ 192 in the US.
} 
to implement domestic policies. Domestic emissions trading and carbon/energy taxes are part of the main domestic economic instruments for complying with the emissions targets. Emissions trading, unlike carbon taxes, is a form of rationing and its great advantage is that in this way one can be sure of achieving the emissions targets. However, the costs of delivering such a guarantee are uncertain. By contrast, the actual achievements in emissions reductions resulting from a carbon tax remain uncertain, because of the imperfect knowledge of price elasticities of demand and supply for fossil fuels, especially for the large price increases caused by carbon taxes for major emissions cutbacks. Nevertheless, a carbon tax provides a greater certainty about the likely costs of complying with the emissions targets, and acts as safety valve in case marginal abatement costs are much higher than expected (see Jacoby and Ellerman (2003) for detailed discussion on the safety valve and climate policy). Whether carbon taxes are a superior or an inferior alternative to emissions trading depends, among other elements, on the degree of uncertainty about marginal damage curves and their correlation with marginal abatement cost curves. Since Weitzman's (1974) contribution, as long as the threshold for severe climate damages remains unknown, this debate on price or quantity controls is expected to continue. In this context, a "hybrid" mechanism combining a carbon tax with an emissions trading system has been proposed (e.g., see Pizer, 1997, 1999). However, without further comparison with emissions trading and other climate policy measures (see Jacoby and Ellerman (2003) for discussion on a price or quantity instrument), this paper has focused exclusively on carbon taxes. This is not to say, however, that carbon taxes are recommended as the sole climate policy measure. Rather, the intention is just to highlight some crucial aspects in designing a domestic carbon tax. 
Several European countries have already implemented energy/carbon taxes to reduce carbon emissions. As an economic instrument, it is widely believed that the introduction of energy/carbon taxes helps to lower the global costs to achieve the required emissions targets in comparison with conventional command-and-control regulations. But it will not avoid all the possible impacts on the international distribution of wealth, on households and on different sectors, especially on carbon-intensive industries and energy consumers. For this reason, in this paper we focus on the evaluation of carbon/energy taxes with respect to their impacts on competitiveness and the distribution of income.

Probably, the main obstacle to implementing carbon taxes is the potential impact on competitiveness. Yet, empirical studies on existing carbon/energy taxes seem to indicate that competitive losses are not significant. However, the history of carbon/energy taxes implementation is relatively recent, their introduction has been gradual, and some peculiarities (e.g., exemptions, ceilings, recycling schemes) are not easy to account for in empirical models. In addition, carbon/energy taxes are often introduced within a more general policy package aimed at reducing emissions and thus their precise impacts are difficult to disentangle from those resulting from environmental policy in general. Nevertheless, commitments to future emissions reductions may imply higher carbon/energy tax rates, with more potential effects on competitiveness than in the past. Even in that case, however, it has been shown that revenue recycling can be a useful way to offset these side effects. On the contrary, rebates and exemptions on trade- and energyintensive industries are less cost-effective and decrease abatement incentives in those sectors that emit the most. 
Concerning the distributive impacts of carbon/energy taxes, the results from empirical studies show that carbon taxes are generally considered to be regressive, but that the overall impact is relatively weak. It should be noted that existing studies only focus on the distribution of costs and they do not incorporate the distribution of benefits from improved environment quality, mainly because they are highly uncertain and difficult to measure, especially in monetary terms. In addition, in many cases, a carefully designed carbon tax, in combination with revenue recycling measures, could address possible regressive impacts, especially if the introduction of carbon taxes is phased in gradually and over a long time period. Therefore, the fiscal revenues generated by the carbon tax are a central element in mitigating its main impacts. However, we have shown that the ways carbon taxes revenues can be used to compensate for the regressive impacts, e.g., lump-sum redistribution or increases in social security benefits, are often not the best options to maximise the efficiency gains from the tax, which may be accomplished with reductions in distortionary taxes, e.g., capital taxes. Thus, there is often a trade-off between efficiency and equity in the use of the carbon tax revenues.

Past experience shows that governments have frequently not opted for just one policy instrument to address a specific environmental issue, but implemented a package of instruments instead. Although the paper focuses exclusively on carbon taxes, in actual practice, governments are expected to implement domestic policies and make use of e of the Kyoto flexibility mechanisms in order to meet their emissions commitments. For example, an Annex B government could allow emissions sources subject to domestic carbon taxes to purchase permits on the international market to reduce their tax liability. In this case, the tax rate relative to the international price of permits is crucial. If the tax 
rate is below the permit price, then the amount of tax revenues could be substantial, because paying the tax is less costly than purchasing permits. If the tax rate is above the permit price, allowing the use of permits in lieu of tax payments improves efficiency, but may put the governments at risk of budgeting. When the government would rely on the carbon tax as a source of revenues, it might be unwilling to risk a substantial reduction in its revenues. Consequently, it might limit the extent to which the permits could be used in order to protect its revenues. A carbon tax on emissions in excess to the allowed emissions levels could also be incorporated as a compliance mechanism into the compliance provisions of the Kyoto Protocol. By setting the tax rate much higher than the permit price, this tax is in fact operating like an excess emissions tax (or a penalty for uncovered emissions) and it will act as an effective deterrent for non-compliance.

\section{Acknowledgements}

Financial support to Andrea Baranzini by the Swiss National Centre of Competence (NCCR) "Climate" is gratefully acknowledged.

\section{References}

Alblas, W. (1997), Energy and Fiscal Reform in The Netherlands, in OECD, Applying Market-based Instruments to Environmental Policies in China and OECD Countries, OECD, Paris, pp. 153-168. 
Bach, S., Kohlhaas, M. and B. Praetorius (1994), Ecological Tax Reform even if Germany Has to Go it Alone, Economic Bulletin, Vol. 31, No. 7, pp. 3-10, DIW German Institute for Economic Research.

Baranzini, A. (1997), International Economic Instruments and Global Warming Mitigation: An Analysis of their Acceptability, Working Paper W54, International Academy of the Environment, Geneva.

Baranzini, A., Goldemberg, J. and S. Speck (2000), A Future for Carbon Taxes, Ecological Economics, Vol. 32, No. 3, pp. 395-412.

Barde, J.P. (1997), Economic Instruments for Environmental Protection: Experience in OECD Countries, in OECD, Applying Market-Based Instruments to Environmental Policies in China and OECD Countries, OECD, Paris, pp. 31-58.

Barker, T. (1992), The Carbon Tax: Economic and Policy Issues, Nota di Lavoro 21.92, Fondazione Eni Enrico Mattei, Milano.

Barker, T. (1995), Taxing Pollution instead of Employment: Greenhouse Gas Abatement through Fiscal Policy in the UK, Energy and Environment, Vol. 6, No. 1, pp. 1-28.

Barker, T., Baylis, S. and P. Madsen (1993), A UK Carbon/Energy Tax: The Macroeconomic Effects, Energy Policy, Vol. 21, No. 3, pp. 296-308.

Barker, T. and J. Köhler (1998), Equity and Ecotax Reform in the EU: Achieving a 10\% Reduction in $\mathrm{CO}_{2}$ Emissions Using Excise Duties, Environmental Fiscal Reform Working Paper No. 10, University of Cambridge, Cambridge.

Baron, R. and ECON-Energy (1997), Economic/Fiscal Instruments: Competitiveness Issues Related to Carbon/Energy Taxation, Policies and Measures for Common Action Working Paper 14, Annex I Expert Group on the UNFCCC, OECD/IEA, Paris. 
Barrett, S. (1991), Global Warming: Economics of a Carbon Tax, in D.W. Pearce (ed.), Blueprint 2: Greening the World Economics, Earthscan, London, pp. 30-52.

Beauséjour, L., Gordon, L. and M. Smart (1995), A CGE Approach to Modelling Carbon Dioxide Emissions Control in Canada and the United States, World Economy, Vol. 18, No. 3, pp. 457-88.

Bill, S. (1999), European Commission's Experience in Designing Environmental Taxation for Energy Products, in J. Hacker and A. Pelchen (eds.), Goals and Economic Instruments for the Achievements of Global Warming Mitigation in Europe, Kluwer, Dordrecht/Boston/London, pp. 231-237.

Böhringer, C. and T.F. Rutherford (1997), Carbon Taxes with Exemptions in an Open Economy: A General Equilibrium Analysis of the German Tax Initiative, Journal of Environmental Economics and Management, Vol. 32, pp. 189-203.

Bovenberg, A.L. (1994), Environmental Policy, Distortionary Labor Taxation, and Employment: Pollution Taxes and the Double Dividend, CentER for Economic Research, Tilburg University, Tilburg, The Netherlands.

Bovenberg, A.L. and L.H. Goulder (1996), Optimal Environmental Taxation in the Presence of Other Taxes: General Equilibrium Analyses, American Economic Review, Vol. 86, No. 4, pp. 985-1000.

Brack, D., Grubb, M. and C. Windram (1999), International Trade and Climate Change Policies, The Royal Institute of International Affairs and Earthscan, London.

Bruvoll, A. and B.M. Larsen (2003), Greenhouse Gas Emissions - Do Carbon Taxes Work?, Energy Policy, Vol. 32. 
Burniaux, J.M., Martin, J.P., Nicoletti, G. and J.O. Martins (1992), GREEN - A MultiSector, Multi-Region General Equilibrium Model for Quantifying the Costs of Curbing $\mathrm{CO}_{2}$ Emissions: A Technical Manual, Working Papers No. 116, Department of Economics and Statistics, OECD, Paris.

CEC (1991), A Community Strategy to Limit Carbon Dioxide emissions and to Improve Energy Efficiency, Commission of the European Communities (CEC), Brussels.

Cline, W.R. (1992), The Economics of Global Warming, Institute of International Economics, Washington, DC.

Delbeke, J. (1997), Environmental Taxes and Charges in the European Union, in OECD, Applying Market-Based Instruments to Environmental Policies in China and OECD Countries, OECD, Paris, pp. 59-64.

DRI (1991), The Economic Impact of a Package of EC Measures to Control $\mathrm{CO}_{2}$ Emissions, Final Report Prepared for the CEC.

Eizenstat, S. (1998), Stick with Kyoto: A Sound Start on Global Warming, Foreign Affairs, Vol. 77, No. 3, pp. 119-121.

Ekins, P. (1998), Ecological Tax Reform, Environmental Policy, and the Competitiveness of British Industry, Policy Briefing No.1, Forum for the Future, London.

Ekins, P. (1999), European Environmental Taxes and Charges: Recent Experiences, Issues and Trends, Ecological Economics, Vol. 31, No. 1, pp. 39-62.

EC (1997), Tax Provisions with a Potential Impact on Environmental Protection. Office for Official Publications of the European Communities, European Commission (EC), Luxembourg. 
European Union (1999), Community Strategy on Climate Change: Council Conclusions, No. 8346/99, 18 May, Brussels.

Felder, S. and T.F. Rutherford (1993), Unilateral $\mathrm{CO}_{2}$ Reductions and Carbon Leakage: The Consequences of International Trade in Oil and Basic Materials, Journal of Environmental Economics and Management, Vol. 25, pp. 162-76.

Feldstein, M. (1999) Tax Avoidance and the Deadweight Loss of the Income Tax, Review of Economics and Statistics, Vol. 81, No. 4.

Godal, O. and B. Holtsmark (1998), Distribution of Costs under Different Regulation Schemes in Norway, Working Paper No. 8, Center for International Climate and Environmental Research, Oslo.

Goulder, L.H. (1995), Environmental Taxation and the Double Dividend: A Reader's Guide, International Tax and Public Finance, Vol. 2, No. 2, pp. 157-183.

Grossman, G.M. and A.B. Krueger (1993), Environmental Impacts of a North American Free Trade Agreement, in P.M. Garber (ed.), The Mexico-U.S. Free Trade Agreement, MIT Press, Cambridge and London, pp. 13-56.

Hoel, M. (1991), Efficient International Agreements for Reducing Emissions of $\mathrm{CO}_{2}$, The Energy Journal, Vol. 12, No. 2, pp. 93-108.

Hoel, M. (1992), International Environment Conventions: The Case of Uniform Reductions of Emissions, Environmental and Resource Economics, Vol. 2, pp. 141-59.

Hoeller, P. and Coppel, J. (1992), Energy Taxation and Price Distortions in Fossil-fuel Markets: Some Implications for Climate Change Policy, in OECD, Climate ChangeDesigning a Practical Tax System, OECD, Paris. 
Hoerner, J.A. (1998), The Role of Border Tax Adjustments in Environmental Taxation:

Theory and U.S. Experience, Presented at the International Workshop on Market-based Instruments and International Trade, Amsterdam, 19-20 March

Hudson, S. (1993), Exploring the Relationship Between Investment, Trade and Environment, in OECD, Environmental Policies and Competitiveness, OECD, Paris, pp. $130-135$.

IPCC (1996), Climate Change 1995: Economic and Social Dimensions of Climate Change, Contribution of Working Group III to the 2nd Assessment Report of the IPCC, WMO and UNEP, Cambridge University Press, New York.

Jacoby, H.D. and and A.D. Ellerman (2003), The Safety Valve and Climate Policy, Energy Policy, Vol. 32.

Jaffe, A., Peterson, P., Portney, P. and R. Stavins (1995), Environmental Regulation and the Competitiveness of US Manufacturing: What Does the Evidence Tell Us?, Journal of Economic Literature, Vol. 33, No. 1, pp. 132-163.

Jorgenson, D.W. and P.J. Wilcoxen (1993a), Reducing US Carbon Emissions: An Econometric General Equilibrium Assessment, Resources and Energy Economics, Vol. 15, No. 1, pp. 7-25.

Jorgenson, D.W. and P.J. Wilcoxen (1993b), Reducing U.S. Carbon Dioxide Emissions: An Assessment of Different Instruments, Journal of Policy Modeling, Vol. 15, Nos. 5\&6, pp. 491-520.

Kågeson, P. (1991), Economic Instruments for Reducing Western European Carbon Dioxide Emission, Swedish Environmental Advisory Council, Ministry of the Environment, Stockholm. 
Karadeloglou, P. (1992), Energy Tax versus Carbon Tax: A Quantitative Macroeconomic Analysis with the HERMES/MIDAS Models, in F. Laroui and J.W. Velthuijsen (eds), An Energy Tax in Europe, SEO Report No. 281, Amsterdam, pp. 127-52.

Kverndokk, S. (1993), Global $\mathrm{CO}_{2}$ Agreement: A Cost-Effective Approach, The Energy Journal, Vol. 14, No. 2, pp. 91-112.

Lee, D.R. and Misiolek, W.S. (1986), Substituting Pollution Taxation for General Taxation: Some Implications for Efficiency in Pollution Taxation, Journal of Environmental Economics and Management, Vol. 13, pp. 338-47.

Manne, A.S. (1994), International Trade: The Impact of Unilateral Carbon Emission Limits, in OECD, The Economics of Climate Change, Proceedings of an OECD/IEA Conference, Paris, pp. 193-205.

Manne, A.S. and R.G. Richels (1991), Global $\mathrm{CO}_{2}$ Emission Reductions - the Impacts of Rising Energy Costs, The Energy Journal, Vol. 12, No. 1, pp. 87-107.

Manne, A.S. and R.G. Richels (1993), The EC Proposal for Combining Carbon and Energy Taxes: The Implications for Future $\mathrm{CO}_{2}$ Emissions, Energy Policy, Vol. 21, No. 1, pp. $5-12$.

Manne, A. and R. Richels (1995), The Greenhouse Debate: Economic Efficiency, Burden Sharing and Hedging Strategies, The Energy Journal, Vol. 16, No. 4, pp. 1-37.

Martin, J.P., Burniaux, J.M., Nicoletti, G. and J.O. Martins (1992), The Costs of International Agreements to Reduce $\mathrm{CO}_{2}$ Emissions: Evidence from GREEN, OECD Economic Studies, No. 19, pp. 93-121.

OECD (1993), The Costs of Cutting Carbon Emissions: Results from Global Models, OECD, Paris. 
Parry, I.W. (1997) Revenue Recycling and the Costs of Reducing Carbon Emissions, Climate Issues Brief No. 2, Resources for the Future, Washington DC.

Parry, I.W., Williams III, R.C. and Goulder, L.H. (1999), When Can Carbon Abatement Policies Increase Welfare? The Fundamental Role of Distorted Factor Markets, Journal of Environmental Economics and Management, Vol. 37, pp. 52-84.

Pearce, D. (1991), The Role of Carbon Taxes in Adjusting to Global Warming, The Economic Journal, Vol. 101, pp. 938-948.

Pezzey, J. (1992), Analysis of Unilateral $\mathrm{CO}_{2}$ Control in the European Community and OECD, The Energy Journal, Vol. 13, No. 3, pp. 159-71.

Pizer, W.A. (1997), Prices vs. Quantities Revisited: The Case of Climate Change, Discussion Paper No. 98-02, Resources for the Future, Washington DC.

Pizer, W.A. (1999), Choosing Price or Quantity Controls for Greenhouse Gases, Climate Issues Brief No. 17, Resources for the Future, Washington DC.

Poterba, J.M. (1991), Designing in a Carbon Tax, in R. Dornbusch and J.M. Poterba (eds.), Global Warming: Economic Policy Response, The MIT Press, Cambridge, Massachusetts.

Poterba, J. M. (1993), Global Warming Policy: A Public Finance Perspective, Journal of Economic Perspectives, Vol. 7, No. 4, pp. 47-63.

Poterba, J.M. and J.J. Rotemberg (1995), Environmental Taxes on Intermediate and Final Goods When Both Can Be Imported, International Tax and Public Finance, Vol. 2, pp. 221-228. 
Shah, A. and B. Larsen (1992), Carbon Taxes, the Greenhouse Effect, and Developing Countries, Policy Research Working Papers No. 957, The World Bank, Washington, DC.

Smith, S. (1992), Distributional Effects of a European Carbon Tax, Nota di Lavoro 22.92, Fondazione Eni Enrico Mattei, Milano.

Speck, S. (1999), Energy and Carbon Taxes and their Distributional Implications, Energy Policy, Vol. 27, pp. 659-667.

Sprenger, R.-U. (1998) Environmental Policy and International Competitiveness: The Case of Germany, in T. Barker and J. Köhler (eds.), International Competitiveness and Environmental Policies, Edward Elgar, Cheltenham, England, pp. 197-240.

Standaert, S. (1992), The Macro-Sectoral Effects of an EC-Wide Energy Tax, in F. Laroui and J.W. Velthuijsen (eds), An Energy Tax in Europe, SEO Report No. 281, Amsterdam, pp. 27-63.

Stewardson, R. (1994), The Case of Carbon Taxes, in OECD, Trade and Environment: Process and Production Methods, OECD, Paris, pp. 93-108.

Thalmann, Ph. (2001), The Public Acceptance of Green Taxes: 2 Million Voters Express Their Opinion, NCCR WP-4 Working Paper No. WP4-1, University of Geneva, Geneva.

Weitzman, M.L. (1974), Prices vs. Quantities, Review of Economic Studies, Vol. 41, pp. 477-491.

Whalley, J. (1991), The Interface between Environmental and Trade Policies, The Economic Journal, Vol. 101, pp. 180-89. 
Whalley, J. and R. Wigle (1991a), Cutting $\mathrm{CO}_{2}$ Emissions: The Effects of Alternative Policy Approaches, The Energy Journal, Vol. 12, No. 1, pp. 109-24.

Whalley, J. and R. Wigle (1991b), The International Incidence of Carbon Taxes, in R. Dornbusch and J. Poterba (eds), Global Warming: Economic Policy Responses, MIT Press, Cambridge, pp. 71-97.

WTO (1995), The Results of the Uruguay Round of Multilateral Trade Negotiations: The Legal Texts, World Trade Organization (WTO), Geneva.

Zamparutti, A. and J. Klavens (1993), Environment and Foreign Investment in Central and Eastern Europe: Results from a Survey of Western Corporations, in OECD, Environmental Policies and Competitiveness, OECD, Paris, pp. 120-129.

Zhang, Z.X. (1997), The Economics of Energy Policy in China: Implications for Global Climate Change, New Horizons in Environmental Economics Series, Edward Elgar, Cheltenham, England and Northampton, USA.

Zhang, Z.X. (2000), Estimating the Size of the Potential Market for the Kyoto Flexibility Mechanisms, Weltwirtschaftliches Archiv - Review of World Economics, Vol. 136, No. 3, pp. 491-521.

Zhang, Z.X. (2001), An Assessment of the EU Proposal for Ceilings on the Use of Kyoto Flexibility Mechanisms, Ecological Economics, Vol. 37, No. 1, pp. 53-69. 